\title{
Evaluation of Antibiotic Resistant Gene in Abattoir Environment
}

\section{*1'ETINOSA O. IGBINOSA; IFEYINWA S. OBUEKWE}

Department of Microbiology, Faculty of Life Sciences, University of Benin, Private Mail Bag 1154 Benin City, Nigeria

KEYWORDS: Abattoir, Class 1 integron, Pseudomonas aeruginosa, Multi-resistance, Gene cassette

\begin{abstract}
Pseudomonas aeruginosa is a ubiquitous gram-negative pathogen with susceptibility to cause opportunistic infections in humans. Among the total of 75 isolated presumptive Pseudomonas aeruginosa, by cultural and morphology characteristic, 55 were identified as Pseudomonas aeruginosa by the specie-specific primer employing PCR assay which was more sensitive for confirmation of the isolates. Fifty-five Pseudomonas aeruginosa isolates were screened using PCR for the presence of integrons and associated resistance gene cassette. Thirty-four isolates harbored class 1 integrons (61.8\%), of which 27 isolates (79.4\%) carried gene cassettes. PCR was performed targeting the presence of these genes:- bla $a_{O X A}$ 11(32.4\%); bla $_{I M P}$ 5(14.7\%); bla $_{A M P} C$ 5(14.7\%); bla $_{T E M} 4(11.8 \%)$; and TetC 2(5.8\%). Some of these genes were only recently described from clinical isolates, demonstrating genetic exchange between clinical and environmental Pseudomonas aeruginosa stains. Multiresistance was observed in the isolates, revealing strong correlation between integron presence and multi-resistance. These results demonstrate that abattoir milieu is potential reservoirs of various antibiotics resistance genes, thus constituting a serious health risk to the communities dependent on the receiving water bodies. () JASEM
\end{abstract}

\section{$\underline{\text { http://dx.doi.org/10.4314/jasem.v18 i2.3 }}$}

Introduction: Pseudomonas aeruginosa is a leading cause of hospital-acquired infections, giving rise to a wide range of opportunistic infections. Its high intrinsic resistance to antibiotics and ability to develop multidrug resistance pose serious therapeutic problems (Kohler et al., 1999). Pseudomonas aeruginosa is highly ubiquitous in water systems, and has intrinsic antimicrobial resistance due to low outer membrane permeability, as well as an extensive efflux pump system (Aeschlimann 2003; Lister et al., 2009). P. aeruginosa demonstrates resistance to multiple antibiotics, thereby rendering common antibiotic therapy ineffective (Bodey et al., 2008). The presence of multidrug-resistant $P$. aeruginosa in an aquatic milieu may be important for immunesuppressed or other at-risk individuals, for whom treatment difficulties have greater implications (Obritsch et al., 2004). P. aeruginosa frequently acquires additional resistance mechanisms (plasmids) and routinely develops multidrug resistance throughout the course of a treatment regimen (Lister et al., 2009).

The integrase (Intl) is the signature of an integron. To date, three classes of integrons (class 1, 2, and 3) have been described to be associated with resistance gene cassettes (Strokes and Hall, 1989). Class 1 is recognized as the most widespread among environmental isolates (Recchia and Hall, 1995; Collis et al., 1998). Various resistance associated genes are harbored in class 1 integron found in $P$. aeruginosa, including those encoding extendedspectrum- $\beta$-lactamases (ESBLs) and metallo- $\beta$ - lactamases that hydrolyse third and fourth generations of cephalosporins and carbapenems respectively (Weldhagen et al., 2004).

Naturally, this pathogen is endowed with weak pathogenic potentials. However, its profound ability to survive on inert materials, its minimal nutritional requirement, tolerance to a variety of physical conditions and its relative resistance to several unrelated antimicrobial agents and antiseptics, contributes enormously to its ecological success and its role as an effective opportunistic pathogen (Gales et al., 2001). The organism is pathogenic when introduced into area devoid of normal defence (Jawetz et al., 1991) and its infections are both invasive and toxigenic (Todar, 2005). It has been widely reported that the susceptibility of this pathogens to antibiotics varies with time and geographical location. $P$. aeruginosa accounts for significant proportion of nosocomial infections and the tendency of nosocomial pathogen to develop or acquire new antibiotics resistance traits poses a great problem in their treatment and control.

Igbinosa et al. (2012) reported that multidrug resistance in $P$. aeruginosa population is a pervasive and growing environmental problem, which is recognized as a threat to public health. Consequently, there is a need to conduct area-specific monitoring studies to profile different pathogens responsible for specific infections and their resistance patterns, so as to generate data that would help clinicians to choose the correct empirical treatment. This paper reports the 
occurrence of some antibiotic resistant genes in Pseudomonas aeruginosa recovered from abattoir environments in Benin City, Nigeria.

\section{MATERIALS AND METHODS}

Bacterial Strain: A total of Seventy-five presumptive Pseudomonas aeruginosa were isolated from abattoir environment in our previous work (Igbinosa et al., 2012). The isolate identification was determined by phenotypic characteristics and standard biochemical reaction using API 20 NE system (bioMerieux, Marcy l'Etoile, France).

Antimicrobial Susceptibility Testing: The antimicrobial susceptibility was carried out as described by Igbinosa et al. (2012). Agar dilution susceptibility testing was employed. Amikacin, aztreonam, cefepime, ciprofloxacin, piperacillintazobactam, ceftazidime, imipenem and meropenem were used to prepare antibiotic stock solutions as described by CLSI (2006). A 1:10 dilution was made of each antibiotic stock solution to be tested to obtain a final concentration of $2,560 \mu \mathrm{g} / \mathrm{ml}$. An agar dilution series $(0.125-512 \mu \mathrm{g} / \mathrm{ml})$ was set up according to CLSI (2006) procedure. Colonies of overnight culture on Mueller-Hinton agar medium were used to prepare and adjust inoculums as described by CLSI (2006). A $200 \mu \mathrm{l}$ of each microbial suspension was placed into the wells of an inoculum. A growth control agar plate without antibiotics was inoculated first; thereafter all plates were inoculated starting with the lowest concentration. The inoculated spots were left to dry after which the inoculated agar plates were incubated at $37^{\circ} \mathrm{C}$ for 18 to $24 \mathrm{~h}$.

Isolation of Genomic DNA: Genomic DNA was extracted following a modified scheme of Igbinosa et al. (2012). Single colonies of $P$. aeruginosa strains grown overnight at $37^{\circ} \mathrm{C}$ on nutrient plates were picked, suspended in $100 \mu 1$ of sterile double distilled water and the cells were lysed using Heat Block for $15 \mathrm{~min}$ at $100^{\circ} \mathrm{C}$. The cell debris was removed by centrifugation at $11,000 \mathrm{~g}$ for 2 min using a MiniSpin micro centrifuge and the supernatant used directly as template DNA or stored at $-20^{\circ} \mathrm{C}$ until ready for use.

Specie-specific Identification: PCRs were performed in $22.5 \mu 1$ volume of reaction buffer containing 0.05 unit/ml Taq polymerase as recommended by the manufacturer (Fermentas Life Sciences) and $2.5 \mu \mathrm{l}$ of DNA template. Sterile double distilled water was included in each PCR assay as a negative control and positive controls contained DNA templates of $P$. aeruginosa ATCC 27853. All PCR was conducted using a MultiGene Thermal Cycler (Labnet International Inc., Edison, NJ, USA), at the following conditions: $95^{\circ} \mathrm{C}$ for $1 \mathrm{~min}$; 40 cycles of denaturation at $95^{\circ} \mathrm{C}$ for $15 \mathrm{~s}$, annealing at $58^{\circ} \mathrm{C}$ for $20 \mathrm{~s}$; final extension at $68^{\circ} \mathrm{C}$ for $40 \mathrm{~s}$ and holding temperature of $4^{\circ} \mathrm{C}$. The primers used were: pa722F (5'-GGC GTG GGT GTG GAA GTC-3') and pa899R (5'-TGG TGG CGA TCT TGA ACT TCTT-3') amplicon size of 199 bp (Lutz and Lee, 2011). Electrophoresis of amplicons was performed with $1 \%$ agarose gel (Hispanagar, Spain) containing ethidium bromide (EtBr) $0.5 \mathrm{mg} / \mathrm{L}$ (Merck, SA) for $1 \mathrm{~h}$ at $100 \mathrm{~V}$ in $0.5 \times$ TAE buffer (40 mM Tris-HCl, $20 \mathrm{mM}$ Na-acetate, 1 $\mathrm{mM}$ EDTA, $\mathrm{pH}$ 8.5) and visualized under an UV transilluminator (BioDoc-It System, UVP Upland, CA 91786, USA).

Detection of Antibiotics Resistance Genes: Polymerase chain reaction (PCR) was used to detect antibiotic resistant elements in the $P$. aeruginosa using the specific primers. PCR conditions for detection of the class 1 integrons was determined as described elsewhere (Fonseca et al., 2005), while $b l a_{I M P}, b l a_{O X A}, \quad b l a_{T E M}, \operatorname{Tet}(C)$, and $b l a_{A M P} C$ genes were based on protocols listed in Table 1. PCRs were performed in $45 \mu \mathrm{l}$ volume of reaction buffer containing 0.05 unit/ml Taq polymerase as recommended by the manufacturer (Fermentas Life Sciences) and $5 \mu \mathrm{l}$ of DNA template. Sterile Milli-Q PCR grade water (Merck, SA) was included in each PCR assay as a negative control. Cycling conditions (MultiGene Thermal Cycler) were as follows for $b l a_{I M P}$, and $b l a_{O X A}$, genes: - initial denaturation at $94^{\circ} \mathrm{C}$ for $5 \mathrm{~min}$ followed by 30 cycles of denaturation at $96^{\circ} \mathrm{C}$ for $30 \mathrm{~s}$, annealing at $55^{\circ} \mathrm{C}$ for $30 \mathrm{~s}$ and elongation at $72^{\circ} \mathrm{C}$ for $1 \mathrm{~min}$ with a final extension at $72^{\circ} \mathrm{C}$ for $5 \mathrm{~min}$. bla $a_{T E M}$ gene $\left(3 \mathrm{~min}\right.$ at $93^{\circ} \mathrm{C}, 40$ cycles of $1 \mathrm{~min}$ at $93^{\circ} \mathrm{C}, 1 \mathrm{~min}$ at $55^{\circ} \mathrm{C}$ and $1 \mathrm{~min}$ at $72^{\circ} \mathrm{C}$ and finally $7 \mathrm{~min}$ at $\left.72^{\circ} \mathrm{C}\right) ; b^{\circ} a_{A M P} \mathrm{C}$ gene $\left(94^{\circ} \mathrm{C}\right.$ for $5 \mathrm{~min}, 30$ cycles of $25 \mathrm{~s}$ of denaturation at $94^{\circ} \mathrm{C}$, $40 \mathrm{~s}$ of annealing at $53^{\circ} \mathrm{C}$ and $50 \mathrm{~s}$ of extension at $72^{\circ} \mathrm{C}$ and a final cycle at $7 \mathrm{~min}$ at $\left.72^{\circ} \mathrm{C}\right) ; \operatorname{TetC}$ gene ( $3 \mathrm{~min}$ at $94^{\circ} \mathrm{C}$, followed by 30 cycles of $1 \mathrm{~min}$ at $94^{\circ} \mathrm{C}, 1 \mathrm{~min}$ at $65^{\circ} \mathrm{C}$ and $1 \mathrm{~min}$ at $72^{\circ} \mathrm{C}$ followed by $10 \mathrm{~min}$ at $\left.72^{\circ} \mathrm{C}\right)$. Ten microlitres $(10 \mu \mathrm{l})$ of reaction mix containing PCR products was analysed by electrophoresis in $1 \%(\mathrm{w} / \mathrm{v})$ agarose.

\section{RESULTS AND DISCUSSION}

Integron Detection and Resistance Genes Characterization: A total of 75 presumptive $P$. aeruginosa, by cultural and morphology characteristic were isolated, 55 were identified as $P$. aeruginosa by the specie-specific primer employing PCR assay which was more sensitive in the confirmation of the isolates. All 55 P. aeruginosa isolates tested for susceptibility to antibiotics were screened for the presence of class 1 integron. Thirtyfour isolates harbored class 1 integrase $(61.8 \%)$, of which 27 isolates $(79.4 \%)$ carried resistance genes associated with class 1 integron. In order to establish the prevalence of these genes in association with class 1 integron, PCR was performed targeting the presence of these genes: - bla OXA $11(32.4 \%)$; bla $_{I M P}$ 
5(14.7\%); bla AMP $_{\text {C } 5(14.7 \%) ; ~}$ bla $_{T E M} 4(11.8 \%)$; and TetC 2(5.8\%) (Table 2).

The rapid dissemination of antibiotic resistance genes among bacterial isolates is an increasing problem in infectious disease. Pseudomonas aeruginosa is a leading cause of nosocomial infections with a high propensity to develop, acquire or transfer antimicrobial resistance genes (Gales et al., 2001). This phenomenon is associated with increased rates of morbidity, mortality and high cost of treatment (Kohler et al., 2001). Previous studies have shown that a conserved DNA sequence, integron may be carried on these episomal genetic structure (Stokes and Hall, 1989; Rowe-Magnus and Mazel, 1999). Integrons possess two conserved segments separated by a variable region that includes integrated cassettes, which often include antibiotic resistance genes (Recchia and Hall, 1995). Many resistance genes are present as gene cassettes within integrons, which may themselves be located on transmissible plasmid and transposon (Recchia and Hall, 1995). Our study revealed that integrons were widely distributed among environmental isolates of $P$. aeruginosa from abattoir locale in Benin City, Nigeria with integrase gene amplicons obtained from $61.8 \%$ (34/55) (Table $2)$. This is comparable with previous reported frequencies of $41.5 \%$ in Brazil (Fonseca et al., 2005), $60 \%$ in the United Kingdom (A. baumannii) (Turton et al., 2005), 43\% in Europe (gram-negative isolates) (Martinez-Freijo et al., 1998), $>50 \%$ in The Netherlands (Enterobacteriaceae) (Jones et al., 1997), 59\% in France (Enterobacteriaceae) (Sallen et al., 1995), and 52\% in Taiwan (Escherichia coli) (Chang et al., 2000).

In this study we compared susceptibility data from integron positive $P$. aeruginosa isolates. It was observed that integrons were significantly associated with resistance to certain antibiotics, including aminoglycosides, quinolones and beta-lactam antibiotics. This is not surprising, since many antibiotics resistance gene cassette encoding resistance to a wide range of antibiotics have been reported previously (Sallen et al., 1995; RoweMagnus and Mazel, 1999; Igbinosa et al., 2012). Multiple antibiotics resistance defined as resistance to six or more antibiotics, correlated strongly with the presence of integrons (Table 2). It is well-known that multiple mechanisms are related to antibiotic resistance in $P$. aeruginosa (Livermore, 2002), and the integrons role in this species is an additional element in the dynamics of the resistance acquisition.

Multi-drug resistance in environmental isolates might be linked to the uncontrolled disposal of antibiotics and chemicals into the environment creating a selective pressure on these drugs. The use of antibiotics in hospital and the community at large serve as major selective pressure for antibiotics resistant bacteria (Moreira et al., 2002).Nosocomial infections are increasing globally as a result of multi drug resistant pathogens. The existence of metallo- $\beta$ lactamases and extended-spectrum $\beta$-lactamase exhibiting resistance to most $-\beta$-lactams antimicrobial agents greatly complicate the clinical management of patients infected with such multi-drug-resistance strains (Moreira et al., 2002; Pagani et al., 2002). The presence of tetC gene (tetracycline) in the isolates could be attributed to the fact that this antibiotic is used indiscrimately in our environment and could also be as a result of the isolates possession of an intrinsic and acquired resistance mechanism caused mainly by an active efflux system, which efficiently expels the compound from the cell (Kohler et al., 2001). $P$. aeruginosa resistance to antibiotics is a serious problem in clinical and environmental locale in Africa. Similar studies conducted in South Africa, Cote d'Ivoire, Tunisia and Nigeria (Aka et al., 1987; Rotimi et al., 1994; Poirel et al., 2001, 2002; Igbinosa et al., 2012) documented the existence of mult-resistant strain of $P$. aeruginosa responsible for nosocomial infections. In Nigeria, carbapenems (imipenem), beta-lactam antibiotics plus betalactamase inhibitors (piperacillin-tazobactam), aminoglycosides (amikacin), and quinolones (levofloxacin) have often been used to cure $P$. aeruginosa infections (Igbinosa et al., 2012). Our findings thus showed that integron gene element bearing drug resistance markers were moderately distributed in the $P$. aeruginosa strains isolated from our study site. It also revealed the frequency of occurrence of the gene cassettes, bla $a_{O X A}, b l a_{I M P}$, $b l a_{A M P C}, b l a_{T E M}$, and TetC. It is important to monitor the distribution of integron gene in emerging $P$. aeruginosa strains.

Conclusion: To the best of our knowledge, this is the first study that describes the detection of antibiotics resistance genes known to confer resistances to common classes of antibiotics in an abattoir environment in Benin City, Nigeria. These results demonstrate that abattoir effluents are potential reservoirs of various antibiotics resistance genes. Moreover, detection of resistance genes in $P$. aeruginosa strains obtained from the abattoir effluents suggests that these resistance determinants might be further disseminated in habitats downstream, thus constituting a serious health risk to the communities dependent on the receiving water bodies. 
Table 1: Sequence of primers used for detection of antibiotics resistance genes

\begin{tabular}{|c|c|c|c|c|}
\hline Primer & Nucleotide sequence (5' to $\left.3^{\prime}\right)$ & Target gene & Amplicon size bp & Reference \\
\hline bla $_{\mathrm{AMP}} \mathrm{C}-\mathrm{F}$ & GGTATGGCTGTGGGTGTTA & $B l a_{A M P}$ C gene & 882 & Yang et al. (2008) \\
\hline bla $_{\mathrm{AMP}} \mathrm{C}-\mathrm{R}$ & TCCGAAACGGTTAGTTGAG & & & \\
\hline TetC -F & GGTTGAAGGCTCTCAAGGGC & Tet $\mathrm{C}$ gene & 505 & Agers $\emptyset$ and Sandvang, \\
\hline TetC -R & CCTCTTGCGGGATATCGTCC & & & $(2005)$ \\
\hline bla $_{\text {TEM }}-\mathrm{F}$ & AGGAAGAGTATGATTCAACA & Bla $a_{T E M}$ gene & 535 & Wang et al. (2006) \\
\hline bla $_{\text {TEM }}-\mathrm{R}$ & CTCGTCGTTTGGTATGGC & & & \\
\hline Imp-F & CTACCGCAGCAGAGTCTTGG & Bla $_{I M P}$ gene & Variable & Fonseca et al. (2005) \\
\hline Imp-R & AACCAGTTCTGCCTTACCAT & & & \\
\hline Oxa-F & AAGAAACGCTACTCGCCTGC & $B l a_{O X A}$ gene & 478 & Bert et al. (2002) \\
\hline Oxa-R & ССАСТСААСССАТССТАССС & & & \\
\hline Int $1-\mathrm{F}$ & AAAACCGCCACTGCGCCGTTA & Class 1 integrase & Variable & Fonseca et al. (2005) \\
\hline Int $1-\mathrm{R}$ & GAAGACGGCTGCACTGAACG & & & \\
\hline
\end{tabular}

Table 2: Phenotypic and genotypic characterization of Pseudomonas aeruginosa strains and their antibiotics resistance genes

\begin{tabular}{|c|c|c|c|c|c|c|c|}
\hline \multirow{2}{*}{$\begin{array}{l}\text { Isolates code } \\
(n=55)\end{array}$} & \multirow{2}{*}{ Resistance profile $^{\text {a }}$} & \multicolumn{6}{|c|}{ Strain(s) showing presence of gene encoding } \\
\hline & & $B l a_{I M P}$ & Bla $O X A$ & $B l a_{T E M}$ & $\operatorname{Tet}(c)$ & $B l a_{A M P} C$ & $\begin{array}{l}\text { Class 1 } \\
\text { integrase }\end{array}$ \\
\hline DPT14 & Ami, Azt, Mem, Pip, Cef & - & + & - & - & + & + \\
\hline DPT23 & Azt, Pip, Imi, Cef & - & - & - & - & - & - \\
\hline DPT18 & Ami, Pipt, Azt, Mem & - & + & + & - & - & + \\
\hline DPT40 & Ami, Azt, Ceft, Pip & - & - & - & - & - & - \\
\hline DPT25 & Ami, Imi, Mem, Azt & - & - & - & + & - & + \\
\hline DPT15 & Azt, Imi, Cet, Pip & - & - & - & - & - & - \\
\hline DPT8 & Ami, Mem, Pipt, Imi, Pip & + & - & - & - & - & + \\
\hline DPT11 & Cef, Imi, Mem, Pipt & - & - & - & - & - & + \\
\hline UPST30 & Ami, Pipt, Azt, Mem & - & - & - & - & - & + \\
\hline UPST45 & Ceft, Azt, Pip, Ami, Cef & - & - & + & - & - & + \\
\hline UPST5 & Ceft, Imi, Azt, Pipt & - & + & - & - & - & + \\
\hline DWST31 & Ami, Ceft, Azt, Mem & - & - & - & + & - & + \\
\hline DWST51 & Ami, Azt, Mem, Pip & - & - & - & - & - & - \\
\hline DWST2 & Ami, Mem, Imi, Pipt & - & - & - & - & - & - \\
\hline DWST30 & Ami, Imi, Cef, Azt & - & - & - & - & - & + \\
\hline DWST18 & Imi, Azt, Ceft, Ami & - & - & - & - & - & + \\
\hline DWST34 & Imi, Azt, Ceft, Pip Cef & - & - & - & - & - & + \\
\hline DWST6 & Imi, Ami, Ceft, Azt & - & - & - & - & - & + \\
\hline DWST9 & Mem, Imi, Ami, Pip, Azt, Cef & + & + & - & - & + & + \\
\hline DWST16 & Mem, Imi, Pip, Ceft & - & - & - & - & - & - \\
\hline DWST37 & Mem, Imi, Azt, Cef & - & - & - & - & - & + \\
\hline DWST42 & Pip, Cef, Imi, Ami & - & - & - & - & - & - \\
\hline DWST28 & Azt, Imi, Pipt, Pip & - & - & - & - & - & + \\
\hline UPST35 & Ami, Pipt, Pip, Cef & - & - & - & - & - & - \\
\hline UPST39 & Azt, Imi, Ami, Cef, Ceft & + & + & - & - & + & + \\
\hline UPST27 & Imi, Ami, Azt, Mem & - & + & - & - & - & + \\
\hline ABSU5 & Mem, Azt, Cef, Ceft & - & - & - & - & - & - \\
\hline ABSU9 & Imi, Ami, Pip, Azt, Ceft & + & - & + & - & + & + \\
\hline ABSU36 & Ami, Azt, Cef, Ceft & - & - & - & - & - & - \\
\hline ABSU48 & Cef, Mem, Pip, Ami & - & - & - & - & - & - \\
\hline ABSU23 & Ceft, Imi, Pipt, Azt & - & + & - & - & - & + \\
\hline ABWT33 & Ami, Imi, Mem, Azt & - & - & - & - & - & - \\
\hline ABWT8 & Azt, Imi, Cef, Pip & - & - & - & - & - & + \\
\hline ABWT40 & Ami, Mem, Azt, Cef & - & - & - & - & - & - \\
\hline ABWT45 & Cef, Mem, Imi, Pip & - & - & - & - & - & - \\
\hline DPT10 & Azt, Mem, Cef, Ami, Pip & - & + & - & - & - & + \\
\hline DPT5 & Cef, Pip, Imi, Azt, & - & - & - & - & - & + \\
\hline DPT15 & Ami, Azt, Mem, Pipt & - & - & - & - & - & - \\
\hline DPT45 & Ami, Azt, Ceft, Pip & - & - & - & - & - & + \\
\hline DPT2 & Azt, Mem, Imi, Ami & - & - & - & - & - & - \\
\hline UPSTa & Mem, Ami, Pipt, Azt & - & - & - & - & - & + \\
\hline UPSTc & Azt, Ceft, Pip, Cef Ami, & - & - & - & - & - & + \\
\hline UPSTx & Pipt, Ceft, Azt, Imi & - & - & - & - & - & + \\
\hline UPSTy & Pipt, Ami, Cef, Pip & - & - & - & - & - & - \\
\hline UPSTz & Ceft, Imi, Azt, Cef, Ami & - & + & - & - & - & + \\
\hline DWSTc & Azt, Ami, Mem, Ceft & - & - & - & - & - & + \\
\hline DWSTd & Ami, Pip, Azt, Mem & - & - & - & - & - & - \\
\hline DWSTz & Ami, Imi, Azt, Ceft & - & - & - & - & - & - \\
\hline DWSTy & Imi, Mem, Azt, Pip, Cef, Ami & + & + & + & - & + & + \\
\hline DWSTq & Cef, Mem, Imi, Azt & - & - & - & - & - & + \\
\hline ABWTs & Mem, Azt, Cef, Ceft & - & - & - & - & - & + \\
\hline ABWTd & Imi, Ami, Pip, Azt, Ceft & - & + & - & - & - & + \\
\hline ABSUx & Ami, Imi, Mem, Azt & - & - & - & - & - & - \\
\hline ABSUz & Azt, Imi, Cef, Pip & - & - & - & - & - & + \\
\hline ABWTy & Cef, Mem, Pip, Ami & - & - & - & - & - & - \\
\hline$\%$ Positive & & $5(14.7 \%)$ & $11(32.4 \%)$ & $4(11.8 \%)$ & $2(5.8 \%)$ & $5(14.7 \%)$ & $34(61.8 \%)$ \\
\hline
\end{tabular}

Legend: Ami-Amikacin; Azt-Aztreonam; Pip- Meropenem ${ }^{\text {a} E x t r a c t e d ~ f r o m ~ I g b i n o s a ~ e t ~ a l . ~(2012) ~}$ Piperacillin; Pipt-Piperacillin-tazobactam; Cef- The Scientific World Journal Cefepime; Ceft-Ceftazidime; Imi-Imipenem; Mem- doi:10.1100/2012/308034 


\section{REFERENCES}

Aeschlimann J. (2003). The role of multidrug efflux pumps in the antibiotic resistance of Pseudomonas aeruginosa and other gramnegative bacteria. Pharmacotherapy 23: 916924

Agersø Y., Sandvang D. (2005). Class 1 Integrons and tetracycline resistance genes in Alcaligenes, Arthrobacter, and Pseudomonas spp. isolated from pigsties and manured soil. Applied and Environmental Microbiology 71: 7941-7947.

Aka J., Dosso M., Michel G. (1987) Antibiotic resistance of Pseudomonas aeruginosa: a fact and problem at the University Hospital Center of Cocody (Abidjan). Medecine Tropicale 47: 5359.

Bert F., Branger C., Lambert-Zechovsky N. (2002). Identification of PSE and OXA $\beta$-lactamase genes in Pseudomonas aeruginosa using PCRrestriction fragment length polymorphism. Journal of Antimicrobial Chemotherapy 50:1118.

Bodey G. P., Bolivar R., Fainstein V., Jadeja L. (2008). Infections caused by Pseudomonas aeruginosa. Reviews of Infectious Diseases 5: 279-313.

Chang C. Y., Chang L. L., Chang, Y. H., Lee T. M., Chang S. F. (2000). Characterization of drug resistance gene cassettes associated with class 1 integrons in clinical isolates of Escherichia coli from Taiwan, ROC. Journal of Medical Microbiology 49:1097-1102.

Clinical and Laboratory Standards Institute (CLSI) (2006), Methods for dilution of antimicrobial susceptibility tests for bacteria that grow aerobically, 7th ed. Approved standard M7-A7, Wayne, Pa: Clinical and Laboratory Standards Institute.

Collis C. M., Kim M. J., Stokes H. W., Hall R. M. (1998). Binding of the purified integron DNA integase IntI 1 to integron and cassetteassociated recombination site. Molecular Microbiology 29: 477-490.

Fonseca E. L., Vieira V. V., Cipriano R., Vicente A. C. P. (2005). Class 1 integrons in Pseudomonas aeruginosa isolates from clinical settings in Amazon region, Brazil. FEMS Immunology and Medical Microbiology 44:303-309.

Gales A. C., Jones R. N., Turnidge J., Rennie R., Ramphal R. (2001). Characterization of

${ }^{*}$ ETINOSA O. IGBINOSA; IFEYINWA S. OBUEKWE
Pseudomonas aeruginosa isolates: occurrence rate, antimicrobial susceptibility pattern and molecular typing in the Global SENTRY antimicrobial surveillance program 19971999.Clinical Infectious Disease 32: S146-155.

Igbinosa E. O., Odjadjare E. E., Igbinosa, I. H., Orhue P. O., Omoigberale M. N. O., Amhanre, N. I. (2012). Antibiotic synergy interaction against multidrug-resistant Pseudomonas aeruginosa isolated from an abattoir effluent environment. The Scientific World Journal, Article ID 308034, 5 pages. doi:10.1100/2012/308034

Jawetz E., Melnick J. L., Adelberg, E. A., Brooks, G. F., Butel, S. J., Ornston, L. N. (1991). Pseudomonads, Acinetobacter and uncommon gram-negative bacteria. In: Review of Medical Microbiology, $19^{\text {th }}$ edn. (ed. Jawetz E) Appleton and Langue Publishing Prentice Hall, Los Altos, California, USA, pp. 224-229.

Jones, M. E., Peters, E., Weersink, A. M., Fluit, A., Verhoef, J. (1997). Widespreadoccurrence of integrons causing multiple antibiotic resistances in bacteria. Lancet 349: 1742-1743.

Kohler T, Delden C. V., Curty L. K., Hamrehpour, M. M., Pechere, J. C. (2001) Over expression of the MexEF-OprN multi-drug efflux system affects cell-to-cell signalling in Pseudomonas aeruginosa. Journal of Bacteriology 183: 5213 5222.

Kohler, T., Epp, S. F.,Curty, L. K., Pechere, J. C. (1999). Characterization of MexT, the regulator of the MexE-MexF-OprN multidrug efflux system of Pseudomonas aeruginosa. Journal of Bacteriology 181:6300-6305

Lister P. D., Wolter D. J., Hanson N. D. (2009). Antibacterial resistant Pseudomonas aeruginosa: clinical impact and complex regulation of chromosomally encoded resistance mechanisms. Clinical Microbiology Reviews 22: 582-610.

Livermore, D. M. (2002). Multiple mechanism of antimicrobial resistance in Pseudomonas aeruginosa: our worst nightmare? Clinical Infectious Disease 34: 634-640.

Lutz J. K., Lee J. (2011). Prevalence and antimicrobial-resistance of Pseudomonas aeruginosa in swimming pools and Hot Tubs. International Journal of Environmental Research and Public Health 8:554-564. 
Martinez-Freijo P., Fluit, A. C., Schmitz, F. J., Grek,V. S., Verhoef, J., Jones, M. E. (1998). Class I integrons in gram-negative isolates from different European hospitals and association with decreased susceptibility to multiple antibiotic compounds. Journal of Antimicrobial and Chemotherapy 42:689-696.

Moreira B. M., Pellegrino, F. L. P. C., Teixeira, L. M. (2002). Occurrence of multi-drug-resistance Pseudomonas aeruginosa clone in different hospitals in Rio de Janeiro, Brazil. Journal of Clinical Microbiology 40: 2420-2424.

Obritsch M. D., Fish D. N., MacLaren R., Jung R., (2004). National surveillance of antimicrobial resistance in Pseudomonas aeruginosa isolates obtained from intensive care unit patients from 1993 to 2002. Antimicrobial Agents and Chemotherapy 48: 4606-4610.

Pagani L., Migliavacca, R., Docquier, J. D. (2002). Simple microdilution test for detection of metallo- $\beta$-lactamase production in Pseudomonas aeruginosa. Journal of Clinical Microbiology 40: 4388-4390.

Poirel L, Weldhagen G. F., De Champs, C., Nordmann, P. (2002). A nosocomial outbreak of Pseudomonas aeruginosa isolates expressing the extended-spectrum beta-lactamase GES-2 in South Africa. Journal of Antimicrobial Chemotherapy 49: 561-565.

Poirel L, Weldhagen, G. F., Naas, T., De Champs, C., Dove, M. G., Nordmann, P. (2001). GES-2, a class A beta-lactamase from Pseudomonas aeruginosa with increased hydrolysis of imipenem. Antimicrobial Agents and Chemotherapy 45: 2598-2603.

Recchia G. D., Hall, R. M. (1995). Gene cassettes: a new class of mobile element. Microbiology 141:3015-3027.
Rotimi V. O., Onyenefa, P. I., Banjo, T. O., Ogunsola, F. T., Adenuga, A. (1994). Significance of antibiotics resistance among clinical bacterial isolates in Lagos. West African Journal of Medicine 13: 81-86.

Rowe-Magnus D. A., Mazel, D. (1999). Resistance gene capture. Current Opinion Microbiology 2:483-488.

Sallen B., A. Rajoharison, A., Desvarenne, S., Mabilat, C. (1995). Molecular epidemiology of integron associated antibiotic resistance genes in clinical isolates of Enterobacteriaceae. Microbial Drug Resistance 1:195-202.

Stokes H. W., Hall R. M. (1989). A novel family of potentially mobile DNA elements encoding site specific gene integration functions: integrons. Molecular Microbiology 3: 1669-1683.

Todar K. (2005). Pseudomonas aeruginosa. Todar's Online Textbook of Bacteriology, http://textbookofbacteriology.net/pseudomonas.h tml. [Accessed February 02, 2014]

Turton J. F., Kaufmann, M. E., Glover, J., Coelho, J. M., Warner, M., Pike, R., Pitt, T. L. (2005). Detection and typing of integrons in epidemic strains of Acinetobacter baumannii found in the United Kingdom. Journal of Clinical Microbiology 43:3074-3082.

Wang C., Cai, P., Chang, D., Mi, Z. (2006). A Pseudomonas aeruginosa isolate producing the GES5extended-spectrum beta-lactamase. Journal of Antimicrobial Chemotherapy 57:1261-1262.

Weldhagen G. F. (2004) Integrons and $\beta$-lactamases a novel perspective on resistance. International Journal of Antimicrobial Agents 23: 556-562.

Yang C. H., Lee, S., Su, P., Yang, C. S., Chuang, L. (2008). Genotype and antibiotic susceptibility patterns of drug-resistant Pseudomonas aeruginosa and Acinetobacter baumannii isolates in Taiwan. Microbial Drug Resistance 14:281-288. 